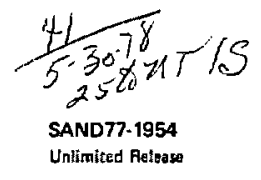

SAND77-1954

Unimited feltase

\title{
MASTER
}

\section{Preliminary Concepts for Detecting National Diversion of LWR Spent Fuel}

C. S. Sonnier, M. N. Crevens

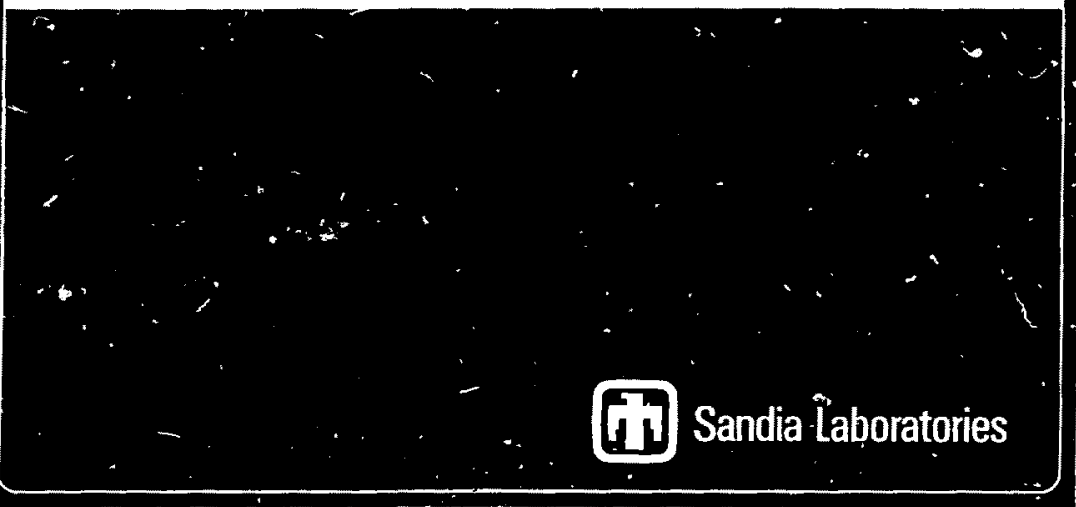




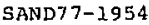

Unlimited Release

printed April 1978

PRELIMINARY CONCEPTS

FOR DETECTING NATIONAL DIVERSION OF

LWR SPENT FUEL

\author{
C. S. Sonnier \\ M. N. Cravens \\ Advanced Facilities Protection bivision \\ jandia laboratories \\ Albuquerque, New Mexico 87185
}

ABSTRACT

Preliminary concepts for detecting national diversion of LWR spont fuel durirtg storage, handing and transportation are presented. Principal emphasis is placed on means to achieve timely detection by an international authority. This work was sponsored by the Department of Energy/Office of Safeguards and Security (DOE/OSS) as part of the overa $7 .$. Sandia Fixed Facility physical protection Frogram. 


\section{ACKNOWLEDGMENTS}

W. F. Lindsay, W. P. Melling, and T. Pasternak of science Applications, Incorporated assisted in the organization and preparam tion of this report. T. A. Sellers of Sandia Laboratorles contributed to the. report ard provided technical review. 


\section{8}

CONTENTS

$\begin{array}{lr}\text { Introduction } & \text { Page } \\ \text { Timeliness of Detection } & 7 \\ \text { Facility and Transportation Safeguards Concepts } & B \\ \text { Facility Concepts } & 12 \\ \text { Facility Concept 1, Periodic Inspections } & 14 \\ \text { Facility Concept 2, Resident Irspectors } & 14 \\ \text { Facility Concept 3, Remote Surveillance with } & 15 \\ \text { Occasional Inspecions } & 16 \\ \text { Transportation Concepts } & 17 \\ \text { Transportation Concept 1, Periodic Shipping/ } & 17 \\ \text { Receiving Comparison } & 18 \\ \text { Transportation Concept 2, Escorts } & 18 \\ \text { Manpower asd Cost Estimates } & 19 \\ \text { Eacility Concepts } & 19 \\ \text { Transportation Concepts } & 22 \\ \text { Conclusions } & 24 \\ \text { References } & 29\end{array}$

ILLUSTRATIONS

Figure

1 Weapon Production Rate (180-day startup time, 21-day fabrication time)

2 Weapon Production Rate (6-day startup time, 6-day fabrication tíne) 


\section{TABLES}

Table

I Nominal Reprocessing plant Capabilities

II Facility Manpower and Cost Estimates 20

III Transportation Manpower and Cost Estimates 23

IV Facility concept Comparison ' 25

V Transportation Concept Comparison $\quad 26$ 
PRELIMINARY CONCEPTS FOR DETECTING

NATIONAL DIVERSION OF LWR SPENT FYEL

\section{Introduction}

In April 1977, the U.S. announced its decision to defer indefinitely the commercial reprocessing and recycling of plutonium produced in U.S. nuclear power programs. In addition, the intention was expressed to continue discussions of a wide range of international approaches and frameworks that would permit all nations to achieve their energy objectives while reducing the spread of nuclear explosives capabilities. Implementation of this policy will increase the requirements for handling and long-term storage of reactor spent fuel.

Large quantities of spent fuel are currently in storage. In the U.S. zlone, there are approximately 12,000 spent fuel assemblies stored in reactor pools and at Away-From-Reactor (AFR) storage facilities, which represent 25,000 to $30,000 \mathrm{~kg}$ of fissile piutonium. ' Assuming no reprocessing, this quantity is expected to double by 1980 . Comparable quantities are, and will be, stored in foreign facilities. This spent fuel represents a target for national diversion as well as subnational acts of sabotage and theft.

Following the April policy announcement, a spent fuel safeguards project, sponsored by the DOE/OSS, was initiated to identify safeguards system performance criteria for the detection of national diversion and for the prevention of acts of theft and sabotage perpetrated by subnational groups. The planned activities of this project include the development and demonstration of the feasibility and performance capability of selected safeguards elements ana subsystems. 
It is the purpose of this document to address the problem of national diversion of reactor spent fuel. Principal emphasis is placed on the derelopment of concepts for the detection of diversion and the establishment of performance measures for comparing these concepts. The subnational tareat is being addressed: in other studies covering concepts for the protection of reactors, spent fuel storage facilities, reprocessing plants, and transportation. ${ }^{2-6}$

\section{Timeliness of Detection}

In the international context, the broad objective of safeguards is "the timely detection of diversion of significant quantities of nuclear material from peaceful nuclear activities to the manufacture of nuslear weapons or of other nuclear explosive devices or for purposes unknown, and deterrence of such diversion by the risk sf early detection." ' Timeliness of detection is related to the time required to convert diverted material to nuclear explosive devices. As discussed in the following paragraphs, this time is estjmated to range from weeks to months if the diverted material is irradiated fuel.

A reprocessing facility is essential to recover the plutonium in reactor spent fuel for use in weapons production. Table I lists some of the reprocessing plants throughort the world t.at have been or are now operating." Assuming $10 \mathrm{~kg}$ of plutonium per weapon, an operating facility with a moderate capacity could produce a sufficient qrantity of plutonium for several nuelear weapons in a few days. In addition, the basic reprocessing technology is well known and although design and construction is a complex and highly technical process, the potential for a clandestine reprocessing plant cannot be ignored.

If several assumptions are made, it is possible to estimate weapon production rates as a function of time from diversion. Let

$$
\begin{aligned}
\mathrm{T}_{1}= & \text { Time to transport diverted spent fuel to a } \\
& \text { reprocessing plant }
\end{aligned}
$$




$$
\begin{aligned}
\mathrm{T}_{2}= & \text { Startup time, after cold testing, for the re- } \\
& \text { processing plant } \\
\mathrm{T}_{3}= & \text { Time to produce enough plutoniur for one weapon } \\
& \text { given an operating plant } \\
\mathrm{T}_{4}= & \text { Time to fabricate a nuclear explosive device } \\
& \text { assuming all nonnuclear parts are available and } \\
& \text { assembled }
\end{aligned}
$$

\begin{tabular}{|c|c|c|}
\hline Plant & $\begin{array}{c}\text { Capacity } \\
\text { (tonnes of spent } \\
\text { fuel per year) } \\
\end{array}$ & $\begin{array}{r}\text { Daily Production of } \\
\text { Fissile plutonium }(\mathrm{kg}) \\
\end{array}$ \\
\hline Italy: Saluggia Eurex 1 & 10 & 0.2 \\
\hline FRG: Karlsruhe & 40 & 0.9 \\
\hline India: Trombay & 60 & 1.3 \\
\hline Belgium: Mol & 60 & 1.3 \\
\hline Japan: Tokai Mura & 200 & 4.5 \\
\hline USA: West Valley, NY & 300 & 6.7 \\
\hline France: La Hague & 800 & 18 \\
\hline
\end{tabular}

then the time to produce the first weapon will be

$$
T \text { (First Weapon) }=T_{1}+T_{2}+T_{3}+T_{4}
$$

TABLE I

Nominal Reprocessing Plant Capabilities 
Subsequent weapons will be produced at intervals of $\mathrm{T}_{3}$ assuming that there are sufficient assembly lines to accomodate the plutonium production rate and that fuel assemblies are diverted at a rate sufficient to support the reprocessing plant. Approximately three pressurized water reactor (FWR) assemblies or elght boiling water reactor (BWR) assemblies would have to be diverted to obtain sufficient plutonium for each weapon. For example, if it is estimated that

$$
\begin{aligned}
T_{1}= & 2 \text { days } \\
T_{2}= & 180 \text { days } \\
T_{3}= & 2 \text { days }(5 \mathrm{~kg} / \text { day } P u \text { output }) \text { to } \\
& 20 \text { days }(0.5 \mathrm{~kg} / \text { day } P(1 \text { output }) \\
T_{4}= & 21 \text { days }
\end{aligned}
$$

then the weapon production rates will be as shown in Figure 1.

A plant plutonium output of $5.0 \mathrm{~kg} /$ day would allow the first weapon to be produced in 205 days. One weapon could be produced every 2 days thereafter. An output of $0.5 \mathrm{~kg} /$ day would allow the first weapon to be produced in 223 days, with one additional weapon being produced every 20 days thereafter.

The value of $T_{1}$ is not expected to vary substantially, and the range of values for $\mathrm{T}_{3}$ is based on the data shown in Table $I$. However, the values of $\mathrm{T}_{2}$ and $\mathrm{T}_{4}$ may vary from those shown. As shown in the example, some estimates of fabrication time $\left(\mathrm{T}_{4}\right)$ are on the order of weeks ${ }^{2} \theta$ while other estimates are either longer or shorter. With the aid of knowledgeable individuals, device fabrication time could possibly be very short. In addition, it is possible that the startup time $\left(\mathrm{T}_{2}\right)$ for a new plant could be more or less than 180 days. Furthermore, a clandestine laboratory or pilot-scale plant could begin processing small anounts of diverted 


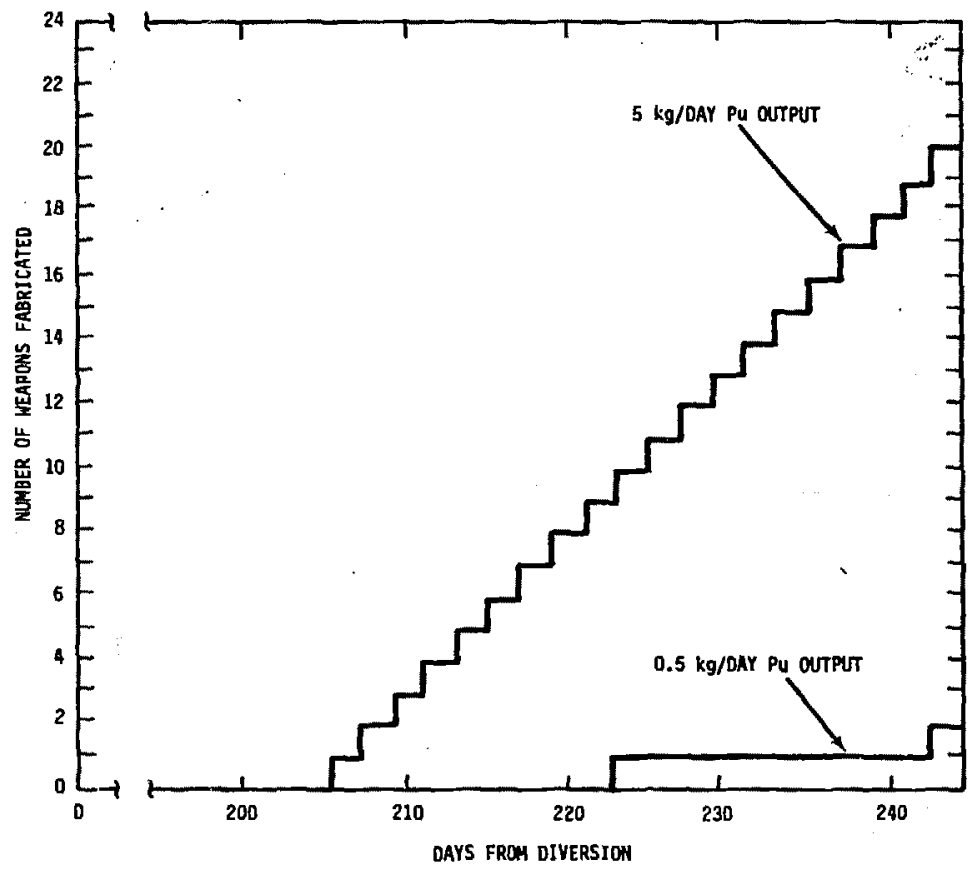

Figure 1. Weapon Production Rate (180-day startup time, 21-day fabrication time) 
fuel without delay. Since reprocessing procedures are well-documented and many plants axe in operation, as indicated by Table $I$, the startup time of a rew, clandestine plant could possibly be very short. If it is assumed that the startup time is 6 days and the fabrication time is aiso 6 days, which is consistert with the lower range of estiuates, then the weapon production rates will be ag shown in Figure 2. In this case, a plant plutonium output of $5.0 \mathrm{~kg} / \mathrm{das}$ would allow the first weapon to be produced in 16 days, with one additional weapon being produced every 2 days thereafter. A plutorium output of $0.5 \mathrm{~kg} /$ day would allow the first weapon to be produced in 34 days, with one weapon produced every 20 days thereafter.

The above production estimates are consistent with the reprocessing time of weeks to monchs noted in Reference 12 . A facility inspection once every few months could provide detection well before the first weapon could be produced if the production requires 205 days or more. However, if a weapon can be produced in 16 to 34 days, and additional weapons every few days thereafter, other detection options must be considered. The remainder of this report examines several safeguards concepts that would provide rimely detection if the actual weapon proauction time is within the range just discussed.

Facility and Transportation Safeguards concepts

This section covers several facility and transportation safeguards concepts. No attempt is made to imply international acceptance of these concepts. They are presented primarily to indicate several meaas for an international authority to dotect a diversion of spent fuel and to show the time relationship between the initiation of a diversion attempt and the detection of such an attempt.

.. International response to a diversion must be preceded by detection and verification.

- Detection is the receipt of an indication by an international authority that an underclared transfer of spent fuel may have 


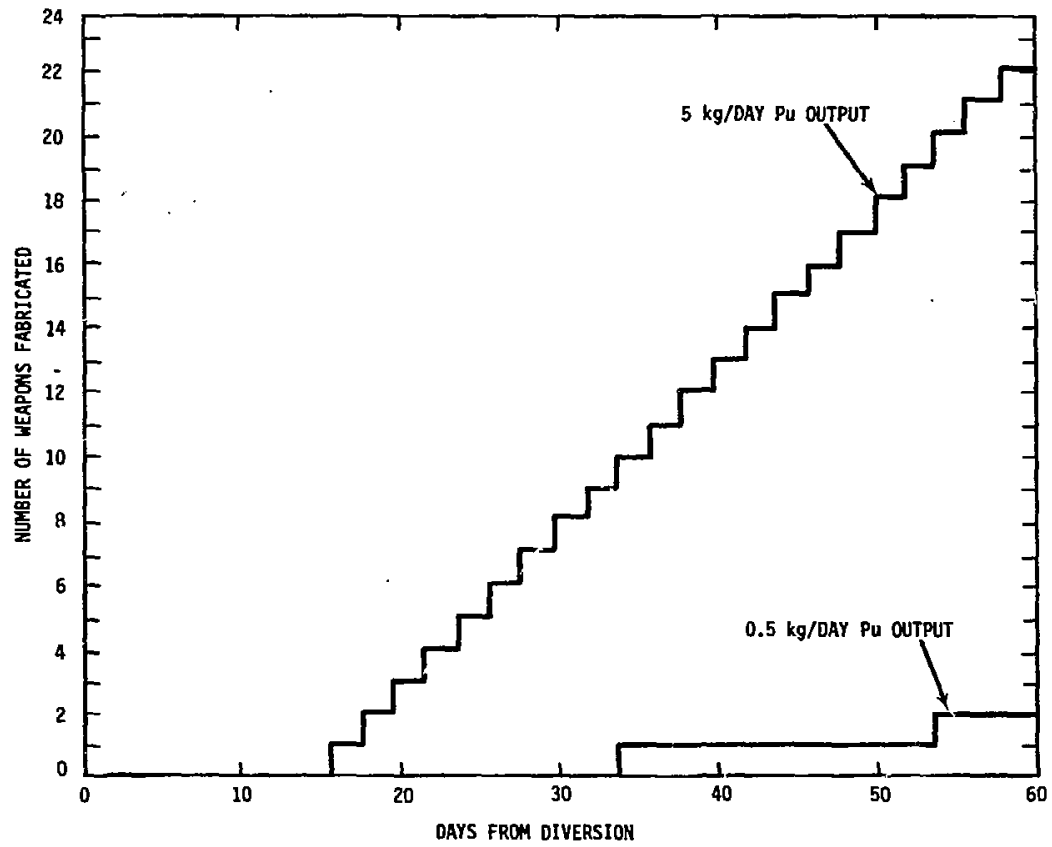

Figure 2. Weapon Production Rate 
occuxred. Declaration by the facility operators/states of intended spent fuel operations is assumed to be provided to the appropriate agencies.

- Verification is the determination by an international authority that a diversion has occurred. It requires independent assessment of the data upon which the detection was based and may be supplemented by:

(1) Additional records and reports from the state or from the facility operator,

(2) Additional data from the site, e.g., physical inventory, and

(3) On-site observation.

The effectiveness and duration of the verification activity could depend on the quality and timeliness of the detection data.

- Response is the set of institutional and political actions that may be set in motion by appropriate international organizations following the verification of a diversion.

The primary role of the safeguards concepts described in this report is the detection of national diversion. The verification and internationi.1 response processes that must follow detection are not considered.

\section{Facility Concepts}

Facilisy Concept 1 , Periodic Inspections -- In this concept, periodic inspection of facilities, each lasting a few days, is employed. i In addition, an inspector is assumed to be present at each reactor auring refueling. The inspector is assumed to be aided by safeguards instrumentation at, the facility, including sensors, closedcircuit television and fuel assembly integrity devices to detect and record áctions which may be related to the diversion of spent fuel. The inspeltor may also use portable instrumentation to aid

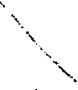


in detection. This instrumentation contributes significartly to detection probability but does not influence timeliness of detection.

On-site instrumentation is not a pivotal point in this study. The same basic on-site instrumentation would be reguired for each facility concept; consequently, specific instrumentation will njt be discugsed in this report. Other studies to define instrumentation requirements and feasibility are in progress.

The duties of the inspector include the following:

- Reviewing accounting records for comparison with previously submitted reports,

- Performing sampling tests to assure tie presence and integitity of the fuel inventory,

- Reviewing the recorded surveillance data, and

- observing the installation and removal of fuel assembly integrity devices.

During the periodic inspections, this system has the capability of providing detection of undeclared removal of spent fuel through discrepancies in records or imbalance in inventories. The delay in detection of diversion is directly related to the time interval between inspections, with the maximum delay occurring when the diversion occurs immediately after the departure of the inspector.

Facility Concept 2, Resident Inspectors -- This concept is based on a resident inspector having continuous access to fuel storage areas, records, and reports. The inspector is assumed to be aided by safeguards instrumentation and portable devices similar to those available in support of the periodic inspection concept descrided previous1y. The duties of the on-site inspector will be similar to those of 
the periodic inspector, but will be performed at a much greater frequency. The on-site inspector may perform additional timely safeguards duties, including

- Inspection of anomalies in spert fuel shipments and schedules,

- Investígation of anomalies detected by the safeguards instrumentation, and

- Spot checks of facility status and operations.

This concept provides the capability for rapid detection of the undeclared removal of spent fuel.

Other factors related to this concept are

- The need for a sufficient number of trained inspectors to accommodate all spent fuel facilities, with the associated yearly cost, and

- The possibility that some states may not be willing to accept the continuous presence of extra-national individuals whose observations canmrt be unequivocally linited to safeguards, e.g., an inspector might become cognizant of matters of an embarrassing or proprietary nature, extraneous to safeguards.

Facility Concept 3, Remote Surveillance with Occasional Insjections -- In this concept, authenticated data from on-site safeguards instrumentation would be transmitted over a tamper-indicating communication link to as off-site monitoring facility where assessment of the safequards status of the spent fuel is made. The data could be transmitted over conventional landlines, high-frequency radio channels, or by satellite. The data transmittals could occur continuously, on a prearranged schedule, or on demand, and may include real-time observations and/or selective replays of the data recorded during periods of nontransmission. The detection of an anomaly in the spent fuel status is made by comparing current observation to a data base stored at the off-site monitoring facility. The frequency of data 
transmission is not necessarily limited by the technical system, but rather will be selected by interpretation of timeliness requirements and cost considerations.

Occasional inspections would be conducted to confirm safeguards instrumentation integrity, and an inspector may be presert at each raactor for the refueling period. other duties of the inspector would be the same as those discussed for Facility concept 1, Feriodic"." Inspections.

This concept can provide rapid detection of the undeclared removal of spent fuel. Further, this concept can provide for detection" of diversion during transport at a time interval equal to the transit time. Cask seals and fuel assembly intes=ity devices could be read upon arrival at the receiving facility, and such information transmitted to the off-site monitoring facility.

Other factors related to this concept are

- Feasibility evaluation and demonstration of this concept would be required.

- While system costs are not yet accurately known, they are likely to be associated mainly with the initial capital j.nvestment.

- Operation is less intrusive than Facility concept 2.

\section{Transportation Concepts}

Transportation Concept 1, Periodic Shipping/Receiving Comparison -- This concept is based on the comparison and correlation of spent fuel transfer records at the origin and destination of shipments, and on the acccuntancy records mainiained at a monitoring agency. The key elements are

- Notification by the shipper of the transfer.

- Notification by the receiver, 
- Use of cask seals and fuel assembly integrity devices by the shipper/receiver to assure the integrity of shipping casks and the fuel within the casks, and

- Periodic on-site inspection of shipment records supplemented by physical inventory.

This system provides for the detection of anomalies in shipment records or in inventories during on-site inspections. It is compatible with all three facility concepts. The timeliness of detection is equal to the inspection time interval or the shipping time interval, whichever is longer.

Transportation Concept 2, Escorts -- This concept, which is applicable to shipment times averaging more than a few days, assumes continuous escort of the transportation vehicle from the point of origin to destination. The key aspects of this system may include

- Frequent notification of the position of the transportation vehicle and the integrity of cask containment, over standard telephone,

- On-site observation of loading and unloading of transported fuel, and

- Use of cask seals and fuel assembly integrity devices by the shipper/receiver to assure the integrity of shipping

.. casks and the fuel within the casks.

This concept has a capability to detect diversion of the shipment during the transit. It is compatible with and similar to the resident inspector capability deycribed in Facility concept 2.

Transportation Concept 3. Remote Surveillance -- This concept is based on a monitoring system which verifies, by a remote communication link, the presence anj integrity of the cask on the transport vehicle during its transit between the origin of shipment and the destination. placement and removal of the spent fuel from the shipping casks is 
verified independently at the shipping and receiving facilities. This concept provides the capability for the detection of cask tampering or. removal of fuel during transit. It is compatible with Facility concept 3, Remote Surveillance. The detection time is dependent on the time interval chosen for communication between the vehicle and the off-site monitoring facility. As in the case of Facility Concept 3 , this concept would require feasibility evaluation and demonstration prior to international implementation.

\section{Manpower, and Cost Estimates}

While the details of the various facility and transportation concepts previously described have not been fully developed, it is useful to compare them in terms of communication mode, reporting interval, number of personnel, and rough estimates of cost. All comparisons are based on a network of 60 power reactors and 3 supporting storage facilities.

\section{Facility Concepts}

Table II compares the three facility concepts. The manpower estimates are based on 240 work days per inspector per year, at $\$ 50,000$ per year per inspector. For Facility Concept 1, Periodic Inspections, two iaspection intervals are shown: bimonthly and monthly. Each inspection including travel time requires 5 days. For Facility concept 2, Resident Inspectors, each facility is monitored 365 days of the year during normal working hours. For Facility concept 3, Remote Surveillance, the off-site monitoring facility is manned by two inspectors 24 hours a day, 365 days a year; a total of 10 personnel would be required to allow for weekends, holidays, and sick leave. In addition, quarterly inspections are assumed. An additional 30 days of inspector presence is assumed to be required at each reactor during the yearly refueling operation for Facility Concepts 1 and 3 . 
TABLE II

Facillty Manpower and Cost Estinates

Annual cost (s Millions) *

\begin{tabular}{|c|c|c|c|c|c|c|c|c|c|}
\hline \multirow[b]{2}{*}{ Facility Concept } & \multirow[b]{2}{*}{$\begin{array}{c}\text { Comburication } \\
\text { nole }\end{array}$} & \multirow[b]{2}{*}{$\begin{array}{l}\text { Reporting } \\
\text { interval }\end{array}$} & \multirow[b]{2}{*}{$\begin{array}{l}\text { Humber of } \\
\text { Personnel }\end{array}$} & \multicolumn{5}{|c|}{ Annual cost (s Hillions) * } & \multirow[b]{2}{*}{ Total } \\
\hline & & & & Manpower & Trave1 & Instrumentation & Cunnunications & $\begin{array}{l}\text { Off-gite } \\
\text { Hoaitoring } \\
\text { Pacility } \\
\text { Equipient }\end{array}$ & \\
\hline \multirow[t]{2}{*}{$\begin{array}{l}\text { 1-perlodic } \\
\text { Inspections }\end{array}$} & $\begin{array}{l}\text { Combercial } \\
\text { Tciephóna }\end{array}$ & $\begin{array}{l}\text { Every } 2 \\
\text { Monthy }\end{array}$ & 15 & 0.75 & 0.28 & 0.63 & & & 1.65 \\
\hline & & Honthly & 22 & 1.1 & 0.57 & 0.63 & & & 2,3 \\
\hline $\begin{array}{l}\text { 2-Resident } \\
\text { Inspectors }\end{array}$ & $\begin{array}{l}\text { Compercial } \\
\text { Telephone }\end{array}$ & Daily & 96 & 4.8 & & 0.63 & & & 5.43 \\
\hline \multirow{3}{*}{$\begin{array}{l}\text { 3-Renoti } \\
\text { Survel l lance }\end{array}$} & HF Radio & Daily & 22 & 1.1 & 0.19 & 0.63 & 0.75 & 0.05 & 2.72 \\
\hline & Leased Line & Da11y & 22 & 1.1 & 0.19 & 0.63 & 1.01 & 0.05 & 2.98 \\
\hline & Satellitw & Daily & 22 & 1.1 & 0.19 & 0.63 & 1.56 & 0.07 & 3.55 \\
\hline
\end{tabular}

"Costs are based on a network of 60 reactor, and 3 storage facilitien.

Hardure costs are based on a 10-year amortization schedule. 
Travel expenses are estimated for each concept bared on a cost of $\$ 750$ per round trip.

Costs for the basic safeguards ingtrumentatior is estimated at $\$ 100,000$ per racility; thig amount is used for all:concepts. It is recognized that the safeguards instrumentation for Facility concept 2 , Resident Inspectors, may not need to be as reliable of tamper resistant and, therefore, may not be as cogtly as instrumentation for the other concepts. This factor is not considered due to the "rough estimate" nature of the cost estimates. Detection, assessment, fuel assembly integrity, and data processing and storage equipment are included in this amount. These costs, and other capital costs, are amortized over a 10-yesr period to provide annual cost estimates.

For Facility Concept 3, three communication modes are compared: high-frequency (hf) radio, leased landines, and sttellite. With this concept, an off-site monitoring facility is required; these are estimated at $\$ 500,000$ for the $h \in$ radio and landline modes and $\$ 700,000$ for the satellite mode. The communications cost for the three modes are based on:

- High-Frequency Radio Mode - 63 transceivers at $\$ 10,000$ each and 63 digital interfaces between the instrumentation and the transceivers at $\$ 100,000$ each. Five reley sites at $\$ 125,000$ each are also required to provide communications over a land area similar to that of the United States.

- Leased Landline Mode - 63 lines at $\$ 6,000$ per year each (based on typical foreign costs of $\$ 6$ per mile and an average, line length of 1000 miles) and 63 digital interfaces between the instrumentation and the landines at $\$ 100,000$ each.

- Satcllite Mode - 63 transceivers at $\$ 100,000$ each, 63 digital interfaces between the instrumentation and the transceivers at $\$ 100,000$ each, and $\$ 300,000$ per year for a dedicated nonpreemptable channel. 


\section{Transportation Concepts}

Table III compares the three transportation concepts. Each of the 60 reactors is assumed to reguire 54 spent fuel shipments per year. A 7-day overland shipping cycle time is assumed, incluaing loadiny, transit, unloading, and cask return. The transit time is assumed to be 2 days. Shipment by rail or sea could take longer.

Only Transportation Concept 2, Escorts, would require additional manpower beyond that required for facility monitoring. Manpower estimates are based on 240 work days per escort per year at $\$ 50,000$ per year per escort.

For all concepts, the casks are assumed to have tamper-resistant seals at $\$ 300$ each.

For Transportation Concept 3, Remote Surveillance, the safeguards instrumentation-to-comunications interface is estimated at $\$ 100,000$ per cask, and includes tamper indicators as well as position location equipment. The communications equipment is estimated as follows:

- High-Frequency Radio Mode - 63 units at $\$ 110,000 \quad(\$ 10,000$ per transceiver and $\$ 100,000$ per digital interface), assuming that the hf radio network has been established, as well as an off-site monitoring facility.

- Satellite Mode - 63 units at $\$ 200,000(\$ 100,000$ per tranceiver and $\$ 100,000$ per digital interface), assuming the use of existing commercial satellites and the establishment of an off-site monitoring facility.

Note that if the 7-day shipping cycle time increased to 30 days, the costs of all transportation concepts would change significantiy. Escort personnel and safeguards instrumentation would be required 
TABLE III

Transportation Nanpower and cost Entimates

\begin{tabular}{|c|c|c|c|c|c|c|c|}
\hline \multirow[b]{2}{*}{$\begin{array}{l}\text { Transportacien } \\
\text { Concupt }\end{array}$} & \multirow[b]{2}{*}{$\begin{array}{c}\text { Cosmunications } \\
\text { Hode }\end{array}$} & \multirow[b]{2}{*}{$\begin{array}{l}\text { Reporting } \\
\text { Interval }\end{array}$} & \multirow[b]{2}{*}{$\begin{array}{l}\text { Number of } \\
\text { zesort } \\
\text { Perronnel }\end{array}$} & \multicolumn{4}{|c|}{ Annual Coet (5 Hilliona) } \\
\hline & & & & Hangover & $\begin{array}{c}\text { Sefequards } \\
\text { Instryantation }\end{array}$ & Conunlcatloan & 고으로기 \\
\hline $\begin{array}{l}\text { 1-Periodic } \\
\text { Shipping/ } \\
\text { Receiving } \\
\text { Congarieon }\end{array}$ & $\begin{array}{l}\text { Pacility } \\
\text { Pquiphent }\end{array}$ & 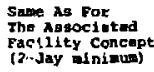 & & & 0,97 & & 0.97 \\
\hline $\begin{array}{l}2 \text {-Escorts } \\
:\end{array}$ & $\begin{array}{l}\text { Comorcial } \\
\text { Telephone }\end{array}$ & [aIly & 95 & 4.8 & 0.97 & & $3 .: 2$ \\
\hline 3-gemote & he padio & oatly & & & 0.97 & 0.59 & 1.66 \\
\hline & Satell1te & Da 1 Iy & & & 0.97 & 1.26 & 2.23 \\
\hline
\end{tabular}

- Costs are based on a notirk of 60 resctors, each requiring 54 ohipmenta of spent fuel per year. ench shiphent is

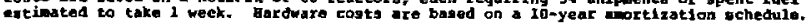


depending on the number of casks needed and how the casks are grouped for shipping. Furthermore, the minimum reporting interval for Transportation concept I would be increased.

\section{Conclusions}

Summary data for the facility and transportation safeguards concepts are presented in Tables IV and V. These summaries allow the reader to compare the basic elements of timeliness and costs. All of these concepts are considered technically feasible; however, institutional and political constraints, which are not considered in this report, may strongly influence the evaluation and ultimate selection of a particular concept.

Three key elements in the initial analysis of these concepts are the reprocessing plant startup time, the daily plutonium production rate, and the device fabricaticn time. A range of times has been considered that encompasses available estimates for these elements. The analysis shows the impact of these estimates on detection timeliness. If the low end of the range of estimates is considered reasonable, then the need for a daily reporting interval is indicated.

All of the concepts described utilize the same types of detection, assessment, and fuel assembly integrity equipment. This equipment is assumed to be highly tamper-resistant and reliable. The required degree of tamper resistance and reliability would depend on the concept chosen. For example, with a resident inspector (Facility concept 2), the necessary degree of tamper resistance may be significantly less than for the unattended remote surveillance concept.

The periodic inspection concepts, with inspection intervals of 1 and 2 months, offer the lowest costs; however, given the initiation of a diversion sequence soon after the inspector(s) departs the facility, 
TABLe IV

Factlity concept comperison

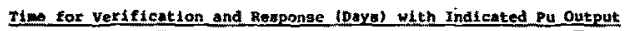
G-Day PTant startup 6-Month Plant sturtup

\begin{tabular}{|c|c|c|c|c|c|c|c|}
\hline \multirow[b]{2}{*}{ Fucility Concept } & \multirow[b]{2}{*}{$\begin{array}{c}\text { Comunication } \\
\text { Yodie }\end{array}$} & \multirow[b]{2}{*}{$\begin{array}{l}\text { Aeporting } \\
\text { Intervel }\end{array}$} & \multicolumn{2}{|c|}{$\begin{array}{l}\text { 6-Day prant startup } \\
\text { 5-Day Fubrieation }\end{array}$} & \multicolumn{3}{|c|}{$\begin{array}{l}\text { 6-Honth Plant Stenxtup } \\
\text { 21-Day Fabrication }\end{array}$} \\
\hline & & & $\begin{array}{l}\text { Annual cos } \\
\text { (s Millions) }\end{array}$ & $5 \mathrm{~kg} / \mathrm{Day}$ & $0.5 \mathrm{~kg} / \mathrm{Bar}$ & $5 \mathrm{~kg} / \mathrm{Dar}$ & $0.5 \mathrm{~kg} / \mathrm{Da}$ \\
\hline \multirow[t]{2}{*}{$\begin{array}{l}\text { 1-Pertodic } \\
\text { Inspections }\end{array}$} & $\begin{array}{l}\text { Comereial } \\
\text { Telephone }\end{array}$ & $\begin{array}{l}\text { Every } 2 \\
\text { Honths }\end{array}$ & 1.7 & $\begin{array}{l}\text { Wone (23 ucapona } \\
\text { produced bafore } \\
\text { detection) }\end{array}$ & $\begin{array}{l}\text { Mene }(2 \text { manpong } \\
\text { produced before } \\
\text { detection) }\end{array}$ & 145 & 163 \\
\hline & & Monthly & 2.3 & $\begin{array}{l}\text { None } 17 \text { weapons } \\
\text { produced before } \\
\text { detection) }\end{array}$ & 4 & 275. & 293 \\
\hline $\begin{array}{l}\text { 2-Rerident } \\
\text { Inspactora }\end{array}$ & $\begin{array}{l}\text { Cotumercial } \\
\text { Teitphone }\end{array}$ & Dadily & 5.4 & 15 & 33 & 204 & 222 \\
\hline \multirow{3}{*}{$\begin{array}{l}\text { 3-Reaste } \\
\text { Survit Lance }\end{array}$} & he Radio & Dhily & 2.7 & 15 & 33 & 204 & 222 \\
\hline & Land Lines & Daily & 3.0 & 15 & 33 & 204 & 222 \\
\hline & Gatellite & oatly & 3.6 & Is & 33 & 201 & 222 \\
\hline
\end{tabular}


TABLE $v$

Transportation Concept Comparimon

Time gor Vexlfigation and Response (Dayg) With indicaked pu output

\begin{tabular}{|c|c|c|c|c|c|c|c|}
\hline \multirow{2}{*}{$\begin{array}{l}\text { Transportation } \\
\text { Concept }\end{array}$} & \multirow{2}{*}{$\begin{array}{c}\text { Conmunication } \\
\text { Mode }\end{array}$} & \multirow{2}{*}{$\begin{array}{l}\text { Reporting } \\
\text { Interval }\end{array}$} & \multirow{2}{*}{$\begin{array}{l}\text { Annual cost } \\
\text { (\$ Milliont) }\end{array}$} & \multicolumn{2}{|c|}{$\begin{array}{l}\text { 6-Day P1ant Stritiup } \\
\text { 6-Day Fabxication }\end{array}$} & \multicolumn{2}{|c|}{ 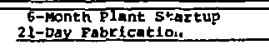 } \\
\hline & & & & $5 \mathrm{~kg} /$ Day & $0.5 \mathrm{~kg} /$ Day & $5 \times g /$ Dax & $0.5 \mathrm{~kg} / \mathrm{c}$ \\
\hline \multirow[t]{3}{*}{$\begin{array}{l}\text { 1-Periodic Ship- } \\
\text { plng/Rccelving }\end{array}$} & $\begin{array}{l}\text { Facility } \\
\text { Equipment }\end{array}$ & $\begin{array}{l}\text { Every Two } \\
\text { Months }\end{array}$ & 1.0 & $\begin{array}{l}\text { None (23 weapons } \\
\text { producad before } \\
\text { detect }\{\text { ion) }\end{array}$ & $\begin{array}{l}\text { None ( } 2 \text { weapon: } \\
\text { produced before } \\
\text { detection) }\end{array}$ & 145 & 163 \\
\hline & & Monthly & 1.0 & $\begin{array}{l}\text { None ( } 7 \text { weapons } \\
\text { produced before } \\
\text { detection) }\end{array}$ & 4 & . 175 & 193 \\
\hline & & $\begin{array}{l}\text { Evary Two } \\
\text { Daye }\end{array}$ & 1.0 & 14 & 32 & 203 & 221 \\
\hline 2-Escorto & $\begin{array}{l}\text { Commercial } \\
\text { Telephone }\end{array}$ & Daily & 5.8 & 15 & 33 & 204 & 222 \\
\hline \multirow{2}{*}{$\begin{array}{l}\text { 3-Remote } \\
\text { Surveil lance }\end{array}$} & he Radio & Dat2y & 3.7 & 25 & 33 & 204 & 222 \\
\hline & satellite & Daily & 2.2 & 15 & 33 & 204 & 222 \\
\hline
\end{tabular}


the detection time is 1 to 2 months. Given the assumption of rapid plant startup, rapid fabrication, and a moderate production rate (5 kg/day), such a detection time would be undesirable since many weapons could be produced before detection.

Eacility Concept 2, Resident Inspectors, provides very rapid detection time at an expense of approximately $\$ 5.4$ million per year-the highest of all concepts presenter. This concept may also present an acceptability problem because of the continuous presence of inspection personnel.

Facility Concept 3, Remote Surveillance, also would provịde very rapid detection time but with reduced inspector presence. The costs for this concept appear to be competitive with the bimonthly or montily inspection concepts, with a reduced detection time. This concept would require a comprehensive evaluation of its feasibility, the development of subsystem elements, and a capability demonstration. The communication options are straightforward adaptations of existi.19 communication systems. Implementation of the hf radio link on ain irternational basis may present a significant problem in the area of frequency allocations. Similarly, implementation of the leased lanaline link may be severely affected by the wide range of existing landline quality.

For the transportatior. concepts, the timeliness of detection is improved by Concept 2, Escorts, or Concept 3, Remote Surveillance. It is assumed that Transportation Concept 3 would not be implemented for transportation on:y; hence, its costs are rather minimal since the basic communications link would be established as part of Facility Concept 3. Should Facility Concept 2 or 3 be implenented, Transportation concept I could then provide a reporting interval equivalent to the transit time (2 days in this example) since the cask seals and fuel assembly integrity devices could be read upon departure and arrival and then data transmitted to the off-site monitoring facility. 
Timeliness of detection and costs are the main themes of this report. Cost differences among the concepts are shown to be relatively minor, but reporting interval differences are significant depending on assumptions made regarding the startup time of a clandestine reprocessing plant, plutonium production rates, and nuclear explosive device fabrication time. Further investigation to resolve startup and fabrication time uncertainties could provide an Improved basis for concept selection. Feasibility ana developmental programs for a variety of safeguards instrumentation and commincation concepts are in progress to assure the availability of appropriate technology for any concept that might be selected for future implementation. 


\section{References}

1. LWR Spent Fuel Disposition Capabilities, ERDA 77-25.

2. John L. Darby and C. P. Cameron, "Preliminary Safeguards Concepts for Typical Light Water Reactors," SAND77-1307, Sandia Laboratories; Albuquerque, New Mexico, to be published.

3. W. David Chadwick, Gary E. Rochau, William C. Fienning, Richard P. Mcknight, and Alfred E. Winblad, "Concept Definition of an Engineered Safeguards system for a spent Fuel Reprocessing Facility," SAND77-1539, Sandia Laboratories, Albuquerque, New Mexico, to be published.

4. C. S. Sonnier, "Baseline Descriptions for Reactor Spent Fuel Storage, Handling and Transportation," SAND77-1953, Sandia Laboratories, Albuquerque, New Mexico, to be published.

5. L. Kull, L. Harris, and P. Lobner, Protection of Nuclear Power Plants Against Sabotage by an Insider, Revision 1, SAI-77-868-IJ Report for Brookhaven National Laboratory, Detober 14, 1977.

6. A. El Bassísni, L. Harris, L. Kull, and P. Lobner, Protection of Nuclear Power Plants Against sabotage by Two Insiders, SAI-77965-LJ Report for Brookhaven National Laboratory, January $6,1978$.

7. The structures and Content of Agreements Between the Agency and States Required in Connection with the Treaty on the Non-Proliferation of Nuclear Weapons, INFCIRC/153; IAEA, May I971.

B. S. Rippon, "Reprocessing - What Went Wrong?" Nuclear Engineering International, Vol. 21, No. 239, P. 24, February 1976.

9. J. R. Clark, "Modifying the West Valley Reprocessing Plant," Nuciear Engineering International, Vol. 21, No. 239, p. 30, February 1976.

10. M. Willrich and T. B. Taylor, Nuclear Theft: Risks and Safeguards, Ballinger Publishing Co., Cambridge, Massachusetts, 1974, p. 21.

11. Memo from D. E. Ferguson, Oak Ridge National Laboratory, to F. L. Culler, Subject: "Simple, Quick Reprocessing Plant," dated 30 August 1977.

12. IAEA Safeguards Technical Manual, IAEA-174, Part A, 1976. 